\title{
Can we farm aquatic insects for human food or livestock feed?
}

\author{
D.D. Williams ${ }^{1 *}$, S.S. Williams ${ }^{2}$ and A. van Huis ${ }^{3}$ \\ ${ }^{1}$ Department of Biological Sciences, University of Toronto Scarborough, 1265 Military Trail, Toronto, ON M1C 1A4, \\ Canada; ${ }^{2}$ The Wildlife Trust, The Manor House, Broad Street, Great Cambourne, Cambridge CB23 6DH, United Kingdom; \\ ${ }^{3}$ Laboratory of Entomology, Wageningen University E Research, P.O. Box 16, 6700 AA Wageningen, the Netherlands; \\ williamsdd@utsc.utoronto.ca
}

\section{OPEN ACCESS (c) (1) (우요}

(c) 2021 Wageningen Academic Publishers

\section{EDITORIAL}

\begin{abstract}
Six of the 12 living orders of aquatic insects contain species engaged in entomophagy, but few are being harvested effectively, leading to overexploitation and local extinction. Existing practices range from including insects (e.g. dipterans) in the core diets of many indigenous peoples to consumption of selected insects as novelty food (e.g. caddisflies). Comparison of nutritional worth of aquatic insects to the human diet and to domestic animal feed are examined. Questions are raised as to whether natural populations of aquatic insects can yield sufficient biomass to be of practicable and sustained use, whether some species can be brought into high-yield cultivation, and what are the requirements and limitations involved in achieving this?
\end{abstract}

\section{Background}

More than 2,100 insect species are recorded to be consumed, chiefly in the tropics and subtropics. The orders with most species are the following in descending sequence: Coleoptera, Lepidoptera (caterpillars), Hymenoptera, Orthoptera, Heteroptera, Odonata, Isoptera, Diptera and others (Jongema, 2017). Insects are also increasingly being used as 'aquafeed' - see recent reviews by Lock et al. (2018) and Hua et al. (2019). Some terrestrial insect food species have advanced to the stage where their yields are very high and sustainable - see the recent rearing successes, on an industrial scale, using mealworms, crickets, houseflies and black soldier flies. Given these advancements in terrestrial insects, the purpose of this article is to explore the potential of aquatic insects in farming for human food and livestock feed.

\section{Aquatic insects}

Of the 30 orders of true insects, 12 are aquatic, or semiaquatic, in either some or all life stages (egg, larva/nymph, pupa, adult). Of these, six contain species known to be eaten by humans, with an estimated 253 named species thought to be edible (Macadam and Stockan, 2017). These range from those (e.g. dipterans) forming the dietary cores of certain indigenous peoples to those such as caddisfly larvae, consumed as 'trendy' snacks (POGOGI, 2012; Polhemus and Polhemus, 2008) by a wealthy few in modern Western society.

Aquatic insects are a hugely diverse group, with around 76,000 species adapted to a wide range of habitats - from cold, freshwater springs, permanent ponds and lakes to large rivers, intermittent streams and phytotelmata - although they are very rare in the oceans (Williams and Feltmate, 2017). Insect orders contain species that are aquatic only in some life stages (e.g. mayflies, stoneflies, dragonflies, caddisflies, and megalopterans), whereas others contain both aquatic and terrestrial species (e.g. beetles, true bugs, neuropterans, orthopterans, and dipterans). Aquatic species live on various forms of decaying organic matter, associated bacteria and hyphomycete fungi. Algae are also grazed, and many species are predators, particularly those in the Odonata (e.g. dragonflies and damselflies), Heteroptera (pond-skaters, giant water bugs and water scorpions), and Coleoptera (diving beetles) (Merritt and Wallace, 2009). Aquatic insects respond to a variety of environmental 
conditions and are increasingly used as indicators of water quality (Hershey and Lamberti, 2001). Their use as human food and livestock feed is another application recently proposed (Williams and Williams, 2017), but while knowledge of terrestrial insect entomophagy is proceeding apace, the same is not true for aquatic insects.

\section{Aquatic insects having the greatest harvesting potential}

Six of the 12 orders of aquatic insects are likely to yield candidate species.

\section{Ephemeroptera}

There are over 3,000 known species of mayfly, the nymphs of which live in a wide range of freshwaters, especially running waters. Their candidacy lies in the ability of some species (e.g. Hexagenia limbata) to emerge from very large rivers in staggering numbers - enough to stop traffic at bridges over the Mississippi River. Although emergence is seasonal, the adults could be harvested and stored in bulk. The possibility of laboratory rearing such species has been trialled, including at elevated water temperatures, to speed up their life cycle. There has been some success (Fremling, 1973; Vancsa et al., 2014/15; Waltz and Burian, 2008). In Malawi, adult Caenis kungu are collected and eaten as dried cakes, and on the shores of Lake Victoria mayflies of the genus Povilla are dried and made into 'insect flour' for meal preparation (Bergeron et al., 1988). The crude protein content of dried mayflies in China has been reported to be 66\% (Chen et al., 2010).

\section{Odonata}

The almost 6,000 species of dragonfly and damselfly are found from the polar tree-line to the tropics, although the greatest diversity occurs in the latter. In China, nymphs of six to seven species are eaten regularly, especially Crocothemis servilia, Gomphus cuneatus and Lestes praemorsa (Feng et al., 2001). In the Neotropics there is a preference for species of the family Aeschnidae. In Laos, the local peoples target individual adult Anax guttatus and capture them as a welcome addition to their diet (Pemberton, 1995). The crude protein content of nymphs varies between 40 and 65\% (Chen et al., 2010).

Trials have successfully reared the lentic species Ischnura ramburii in modest densities $(>1,200)$, using fruit-flies as prey, but yields have yet to be financially viable (Locklin et al., 2012).

\section{Heteroptera}

This order, 'true bugs', with its 3,800 species is perhaps the best-known and most extensively eaten group of aquatic insects. Not only are their nymphs and adults eaten, but also, in Mexico, their eggs (known as 'ahuahutle') - which, in the case of corixids (water boatmen) command a high price (Ramos-Elorduy, 2006; Van Itterbeeck and Van Huis, 2012). Giant water bugs (Belostomatidae) are eaten globally, but in many parts of Asia they are a prised delicacy (Durst and Hanboonsong, 2015; Tao and Li, 2018). In particular, Lethocerus indicus which grows up to $12 \mathrm{~cm}$ in length, is commonly eaten in southeast Asia. They can be caught at lights, to which they are attracted (DeFoliart, 2009; Hanboonsong, 2010), however artificial lights constitute a critical factor in the local extinction of the insect (Yoon et al., 2010). The Rajamangala University of Technology Isan in Thailand seems to have developed a rearing method (Hanboonsong et al., 2013). In other areas conservation techniques are proposed (Wang and Chen, 2018). There is potential for raising lentic species in tanks, with Lethocerus deyrolli responding to farming in Japan (Inoda, 2017; Inoda and Kamimura, 2004). Unfortunately, the highly cannibalistic nature of Lethocerus poses additional problems in designing farming protocols (Hanboonsong et al., 2013). The water-scorpion, Laccotrephes maculatus (Nepidae) is eaten by the indigenous peoples of Manipur, India (Shantibala et al., 2014) and, in Thailand, school children are encouraged to raise insects, including $L$. indicus, to promote nutrition (Yhoung-aree, 2010). Many of the insects consumed are gathered in the rainy season (MayJuly) when their pond and wetland habitats are abundant in the landscape (Williams, 2006). Edible heteropterans particularly attracted to these temporary waterbodies include naucorids (creeping water bugs), notonectids (backswimmers), and gerrids (water striders) (Jongema, 2017). There has been some success in raising multiple generations of some of these smaller bugs in the laboratory, provided that they are supplied with suitable live food, for example as in the case of Notonecta hoffmanni (Hirooka et al., 2016; McPherson, 1966). It should be possible to scale-up some of these methods for greater yield.

\section{Coleoptera}

There are more than 400,000 species of beetle, with roughly 5,000 considered to be aquatic. The latter are found in almost all freshwater habitats. Although key to the proper functioning of their respective ecosystems, lotic species are likely not good candidates for mass harvesting, with the possible exception of riffle beetles (Elmidae) (RamosElorduy et al., 2009). However, lentic dwellers, such as gyrinids and dytiscids, often occur naturally at high densities and might be more suitable. Globally, around 78 species are considered to be edible (Ramos-Elorduy et al., 2009). Mexico leads with 36 species eaten, followed by China 
(Pemberton, 1995), and Japan (POGOGI, 2012). Certain genera are favoured world-wide, with 22 species within the dytiscid genus Cybister recorded as eaten (Jongema, 2017). Cybister tripunctatus is well known for its high fat content and antioxidant properties (Shantibala et al., 2014). In local markets in Guangdong, China, some highly sought after species are now being hatched in purpose-built nurseries (Inoda and Kamimura, 2004; Yhoung-aree, 2010). Parallel, mass rearing of mosquito larvae can provide a steady supply of prey.

\section{Diptera}

There are greater than 120,000 known species of true (two-winged) flies with many yet to be described. Of particular interest are four large aquatic families: Tipulidae (craneflies), Culicidae (mosquitoes), Chironomidae (nonbiting midges), and Simuliidae (blackflies). The adults are typically terrestrial, with the pupae and larvae living in water (Williams and Feltmate, 2017). Populations can be vast in certain habitats where they have been studied largely from a human health perspective (vectors of disease, etc.). Far less studied has been their potential to provide humans with a high-quality food resource. The following are brief examples of these possibilities:

- Tipulidae. Craneflies are abundant in shallow waters where they are important in the break-down of riparian leaves. The larvae and adults are eaten by a wide variety of birds, fishes, amphibians and reptiles (Byers and Gelhaus, 2008), and their high diversity (over 15,000 species) should yield some that are suited to farming - perhaps in leaf-filled, polythene-lined pools. Many species are of a decent size $(1-2 \mathrm{~cm})$ for harvesting, but suitable methods would need to be developed.

- Culicidae. Several of the 3,500 or so of these biting flies have been studied because of the role in their transmission of diseases to humans. However, their global distribution, rapid development, and occurrence at very high densities make them prime candidates for entomophagy in several ways. For example, mass emergences of adult culicids, such as those that take place on the Arctic Tundra (Culler et al., 2015), but which are not yet harvested. In contrast, emerging adults of the culicid sister group, the Chaoboridae, are actively and sustainably collected on the shores of Lake Victoria by local Luo villagers (Ayieko and Oriaro, 2008). At other sites, mass rearing and harvesting of culicids should be possible through scaled-up methods already proven in the laboratory (e.g. Das et al., 2007; Vladimirova, 1966). Additionally, harvested larvae can provide food directly (dried) or provide live prey for cultures of dytiscid beetles and giant water bugs (see above; Chandra et al., 2008).

- Chironomidae. Non-biting midges often occur at very high densities and have a global distribution. Around 5,000 species have been formally described, although in total the species count may exceed 20,000. They are mostly small, but the larvae of some (e.g. species of Chironomus - 'bloodworms') can exceed $1 \mathrm{~cm}$. In the laboratory, the latter can be grown to adult size in as little as 20-22 days. Such cultures would seem to be good candidates for up-scaling to bulk production, particularly as they can be fed on farm manure and waste lagoon effluent on which, over 5 months, the larval yield was $51 \mathrm{~kg}$, wet weight (Bouguenec and Giani, 1992). Further, Shaw and Mark (1980) reported that on a 13.5 ha farm in Hong Kong, chicken manure was successfully used to rear chironomids which were then used to feed fishes - the larval yield being $25 \mathrm{~g} / \mathrm{m}^{2}$ per week. The intervening 40 years do not appear to have produced further examples, although (Bektas and Guler, 2019) have reported the addition of aquatic insects to the feed rations of poultry.

- Simuliidae. Blackflies have been studied extensively due to their blood-sucking behaviour which spreads several human diseases, such as onchocerciasis (river blindness). Worldwide, there are around 1,900 species and, while the adults are terrestrial, the larvae and pupae are confined to rivers and streams where they attach themselves to solid surfaces and feed by filtering food particles from the passing water. Where conditions are favourable, the larvae can reach very high densities (120 per $\mathrm{cm}^{2}$ of rock surface (Malmqvist, 1994) and emerging adults can form dense clouds. Clearly, both life history stages have high potential to be harvested for human food, as the larvae can be easily swept into a net and the adults are attracted by lights. Larvae also rapidly colonise flat, artificial substrates placed in areas of fast current. There are few recorded instances of such harvesting, apart from that of larvae being eaten by certain tribes in northern Thailand (Leksawasdi, 2010). There has been some success in rearing Simulium damnosum in the laboratory, in 1967 (Raybould, 1967), but nothing of significance since.

\section{Trichoptera}

There are of the order of 7,000 known species of caddisfly, all but a few confined to freshwater lotic and lentic habitats, where under favourable conditions they can reach very high densities. For example, where there are fast currents laden with fine particulate organics, larvae of the net-spinning families (e.g. Hydropsychidae) can occur at densities exceeding 1000 larvae per $\mathrm{m}^{2}$. Synchronous emergence of adults from large rivers have resulted in 'shad-fly' plagues - made more troublesome by their attraction to lights in riparian suburbs, as is seen annually in the St. Lawrence and Niagara Rivers of Canada (Resh and Rosenberg, 2015). However, as with similar mass emergences, the biomass harvesting opportunities have been ignored - even if the insects might be collected, dried, and shipped to developing nations, rather than for 'home' consumption. There are some rare examples of entomophagy in caddisflies, most 
notably in Japan where larvae are boiled, sautéed in soya sauce and sugar, and sold as the delicacy 'Zaza-Mushi' (POGOGI, 2012). There are also anecdotal records of caddisflies being eaten in Mexico, and southern Asia (Deutsch and Murakhver, 2012).

\section{Nutrition}

Compared with terrestrial insects, there is very little information available on the nutritional value of aquatic insects. What is known is that the latter, in general, tend to be excellent sources of protein - for example, in mayflies it makes up $66.3 \%$ of their body weight, in odonates it is $40-65 \%$, in heteropterans $42-73 \%$, and beetles $23-66 \%$ (Chen et al., 2010; Shantibala et al., 2014). Insects are high in mineral content (e.g. iron and zinc), B-vitamins, and essential amino-acids (Bergeron et al., 1988; Okedi, 1992). However, they tend to be low in carbohydrates. Eating insects in combination with another source of carbohydrate (such as rice, millet or cassava) could help towards creating a more balanced diet. Newly emerged adult females may have greater fat content in readiness for egg laying; there may be other seasonal variations and changes associated with life-history. Much more basic, quantitative research needs to be done on this aspect of nutrition (but see Bell et al., 1994 and Ayieko et al., 2010b).

\section{Harvesting versus culturing}

Interestingly, aquatic insects already contribute to the diets of some indigenous peoples, through harvesting of natural populations at times dictated by species availabilities. Knowledge of habitats and life cycles is fundamental for this, and likely has been drawn into local folklore and tradition. However, based on this same information there is the potential for culturing edible species, using the simplest of materials - such as creating shallow artificial ponds for attracting migrating adult water-beetles, or raising odonates, or placing flat tiles (or pieces of 'astro-turf') in rivers and streams for colonisation by net-spinning caddisflies or blackflies.

A form of cultivation, akin to mussel farming, has been practiced, historically, in Mexico to gather the eggs of aquatic heteropterans (Van Itterbeeck and Van Huis, 2012). Unfortunately, while there are published methods describing the mass rearing of insects in closed systems, there are relatively few that involve aquatic species (Cohen, 2018; Inoda and Kamimura, 2004). Future emphasis needs to be put on designing such rearing protocols - so that the bulk production success achieved with, crickets, mealworms and flies can be duplicated for aquatic insects. Cross-fertilisation of mass rearing ideas among taxa can be productive (Benedict et al., 2009; Keiper and Foote, 1996; Mason and Lewis, 1970; Yokoyama et al., 2009).

\section{Conclusions}

Of the 30 extant orders of insect, 12 are aquatic or semiaquatic. Of the latter, six are deemed to be already used as food for humans and/or their livestock. However, these usages are, at present, very small. Table 1 summarises both these existing and possible future uses, and gives examples of potential harvesting protocols.

Of these six orders, there are few containing species that are being harvested effectively. Of those that are (e.g. beetles and heteropterans), their management is largely at

Table 1. Summary of the existing and potential use of aquatic insects as food and feed, together with possible protocols for harvesting.

\begin{tabular}{|c|c|c|c|}
\hline Order/Family & Existing & Potential & Harvesting protocol \\
\hline Ephemeroptera & low & could be higher & $\begin{array}{l}\text { netting mass emergences of adults; possible breeding of lentics in tanks and lotics in reversed- } \\
\text { funnel systems }\end{array}$ \\
\hline Odonata & medium & could be higher & individually, via sap on sticks; possible breeding of lentics in tanks \\
\hline Hemiptera & med/high & could be higher & netting and attracted to lights; up-scaling of lab protocols \\
\hline Coleoptera & med/high & could be higher & wild collection of adults; some captive breeding \\
\hline \multicolumn{4}{|l|}{ Diptera } \\
\hline Tipulidae & none & could be viable & netting adults; creation of shallow, leaf-litter-filled pools for larvae \\
\hline Culicidae & none & could be viable & netting of adults where dense \\
\hline Chaoboridae & medium & viable & existing netting of adults where they occur on lake shorelines \\
\hline Chironomidae & low & very high & $\begin{array}{l}\text { wild collection where densities are high; up-scaling of lab-breeding protocols; waste lagoon } \\
\text { rearing; route biomass through carp or Tilapia to improve aesthetics; use as animal feed for } \\
\text { pigs, poultry, cattle }\end{array}$ \\
\hline Simuliidae & very low & could be viable & collection of adults at lights; wild collecting of larvae on flat surfaces in fast water \\
\hline Trichoptera & low & could be higher & $\begin{array}{l}\text { wild-caught for specialist market; same as for simuliids; possibility of rearing lentic species in } \\
\text { tanks/ponds }\end{array}$ \\
\hline
\end{tabular}


a 'hunter-gatherer' stage. Sustainability has hardly entered the equation and, therefore, an increasing number of species have become rare, for example the dytiscid beetle C. tripunctatus and the belostomatid L. indicus. Groups that currently have no or very little engagement with entomophagy are the craneflies (tipulids), biting midges (culicids), and blackflies (simuliids), but all of these have the potential to be higher, giving suitable improvements in rearing technology. Groups currently eaten by people, albeit at a low level, are the mayflies, caddisflies, and nonbiting midges (chironomids) which again, with improved methodologies, have considerably higher potential. The latter applies also to those groups with a current medium engagement with entomophagy, namely the odonates, heteropterans, beetles, and chaoborids (phantom midges). A number of these are, however, facing local extinction if harvesting methods are not broadened to include population-sustainment. Other factors are also taking their toll, such as pollution, use of insecticides, and climate change (Ayieko et al., 2010a; Ramos-Elorduy, 2006).

\section{References}

Ayieko, M.A. and Oriaro, V., 2008. Consumption, indigeneous knowledge and cultural values of the lakefly species within the Lake Victoria region. African Journal of Environmental Science and Technology 2: 282-286.

Ayieko, M.A., Ndong', M.F.O. and Tamale, A., 2010a. Climate change and the abundance of edible insects in the Lake Victoria Region. Journal of Cell and Animal Biology 4: 112-118. https://doi. org/10.5897/JCAB

Ayieko, M.A., Oriamo, V. and Nyambuga, I.A., 2010b. Processed products of termites and lake flies: improving entomophagy for food security within the Lake Victoria region. African Journal of Food, Agriculture, Nutrition and Development 10: 2085-2098.

Bektas, M. and Guler, O., 2019. Usage of edible aquatic insects for feed rations of poultry. International Journal of Scientific and Technological Research 5: 70-80. https://doi.org/10.7176/JSTR/5-5-9 Bell, J.G., Ghioni, C. and Sargent, J.R., 1994. Fatty acid compositions of 10 freshwater invertebrates which are natural food organisms of Atlantic salmon parr (Salmo salar): a comparison with commercial diets. Aquaculture 128: 301-313. https://doi.org/10.1016/00448486(94)90319-0

Benedict, M.Q., Knols, B.G.J., Bossin, H.C., Howell, P.I., Mialhe, E., Caceres, C. and Robinson, A.S., 2009. Colonisation and mass rearing: learning from others. Malaria Journal 8: S4. https://doi. org/10.1186/1475-2875-8-S2-S4

Bergeron, D., Bushway, R.J., Roberts, F.L., Kornfield, I., Okedi, J. and Bushway, A.A., 1988. The nutrient composition of an insect flour sample from Lake Victoria, Uganda. Journal of Food Composition and Analysis 1:371-377. https://doi.org/10.1016/08891575(88)90038-5
Bouguenec, V. and Giani, N., 1992. Mise en place d'un élevage de Chironomus riparius Meigen (Diptera, Chironomidae) à l'aval d'une station d'épuration par lagunage. Annales de Limnologie - International Journal of Limnology 28: 233-243. https://doi. org/10.1051/limn/1992020

Byers, G.W. and Gelhaus, J.K., 2008. Tipulidae. In: Meritt, R.W., Cummins, K.W. and Berg, M.B. (eds) An introduction to the aquatic insects of North America. Kendall Hunt, Dubuque, IA, USA, pp. 773-800

Chandra, G., Mandal, S.K., Ghosh, A.K., Das, D., Banerjee, S.S. and Chakraborty, S., 2008. Biocontrol of larval mosquitoes by Acilius sulcatus (Coleoptera: Dytiscidae). BMC Infectious Diseases 8: 138. https://doi.org/10.1186/1471-2334-8-138

Chen, X., Feng, Y. and Hong, Z., 2010. Review of the nutritive value of edible insects. In: Durst, P.B., Johnson, D.V., Leslie, R.L. and Shono, K.E. (eds) Forest insects as food: humans bite back, proceedings of a workshop on Asia-Pacific resources and their potential for development. Food and Agriculture Organization of the United Nations. Regional Office for Asia and the Pacific, Bangkok, Thailand, pp. 85-92. Available at: http://www.fao.org/3/i1380e/i1380e00.htm.

Cohen, A.C., 2018. Ecology of insect rearing systems: a mini-review of insect rearing papers from 1906-2017. Advances in Entomology 6: 86-115. https://doi.org/10.4236/ae.2018.62008

Culler, L.E., Ayres, M.P. and Virginia, R.A., 2015. In a warmer Arctic, mosquitoes avoid increased mortality from predators by growing faster. Proceedings of the Royal Society B: Biological Sciences 282: 20151549. https://doi.org/10.1098/rspb.2015.1549

Das, S., Garver, L. and Dimopoulos, G., 2007. Protocol for mosquito rearing (A. gambiae). Journal of Visualized Experiments: e221. https://doi.org/10.3791/221

DeFoliart, G.R., 2009. Food, insects. Chapter 102. In: Resh V.H. and Cardé R.T. (eds), Encyclopedia of insects ( $2^{\text {nd }}$ Ed.). Academic Press, San Diego, CA, USA, pp. 376-381. https://doi.org/10.1016/B9780-12-374144-8.00111-9

Deutsch, J. and Murakhver, N., 2012. They eat that? A cultural encyclopedia of weird and exotic food from around the world. ABC-CLIO, Oxford, UK, 234 pp.

Durst, P.B. and Hanboonsong, Y., 2015. Small-scale production of edible insects for enhanced food security and rural livelihoods: experience from Thailand and Lao People's Democratic Republic. Journal of Insects as Food and Feed 1: 25-31. https://doi.org/10.3920/ JIFF2014.0019

Feng, Y., Chen, X.-M., Wang, S.-Y., Ye, S.-D. and Chen, Y., 2001. Three edible odonata species and their nutritive value. Forest Research 14: 421-424.

Fremling, C.R., 1973. Factors influencing the distribution of burrowing mayflies along the Mississippi River. In: Peters, W.L. and Peters, J.G. (eds) Proceedings of the $1^{\text {st }}$ International Conference on Ephemeroptera. Brill, Leiden, the Netherlands, pp. 12-25. Available at: https://openriver.winona.edu/cgi/viewcontent.cgi?article=1038 \&context=calfremlingpapers. 
Hanboonsong, Y., 2010. Edible insects and associated food habits in Thailand. In: Durst, P.B., Johnson, D.V., Leslie, R.L. and Shono, K.E. (eds) Forest insects as food: humans bite back, proceedings of a workshop on Asia-Pacific resources and their potential for development. Food and Agriculture Organization of the United Nations. Regional Office for Asia and the Pacific, Bangkok, Thailand, pp. 173-181. Available at: http://www.fao.org/3/i1380e/i1380e00.htm Hanboonsong, Y., Jamjanya, T. and Durst, P.B., 2013. Six-legged livestock: edible insect farming, collection and marketing in Thailand. Food and Agriculture Organization of the United Nations, Regional Office for Asia and the Pacific, Bangkok, Thailand. Available at: http://www.fao.org/3/i3246e/i3246e00.htm.

Hershey, A.E. and Lamberti, G.A., 2001. Aquatic insect ecology. Chapter 18. In: Thorp J.H. and Covich A.P. (eds) Ecology and classification of North American freshwater invertebrates (2 ${ }^{\text {nd }}$ Ed.). Academic Press, San Diego, CA, USA, pp. 733-775. https:// doi.org/10.1016/B978-012690647-9/50019-3

Hirooka, Y., Hagizuka, C. and Ohshima, I., 2016. The effect of combinations of food insects for continuous rearing of the wing polymorphic water strider Limnogonus Fossarum fossarum (Hemiptera: Gerridae). Journal of Insect Science 16: 80. https:// doi.org/10.1093/jisesa/iew059

Hua, K., Cobcroft, J.M., Cole, A., Condon, K., Jerry, D.R., Mangott, A., Praeger, C., Vucko, M.J., Zeng, C., Zenger, K. and Strugnell, J.M., 2019. The future of aquatic protein: implications for protein sources in aquaculture diets. One Earth 1: 316-329. https://doi. org/10.1016/j.oneear.2019.10.018

Inoda, T., 2017. Giant water bug. Available at: www5f.biglobe. ne.jp/ Dytiscus/TAGAME/intro.htm.

Inoda, T. and Kamimura, S., 2004. New open aquarium system to breed larvae of water beetles (Coleoptera: Dytiscidae). The Coleopterists Bulletin 58: 37-43. https://doi.org/10.1649/591

Jongema, Y., 2017. List of edible insect species of the world. Wageningen University \& Research, Wageningen, the Netherlands. Available at: http://tinyurl.com/mestm6p.

Keiper, J.B. and Foote, B.A., 1996. A simple rearing chamber for lotic insect larvae. Hydrobiologia 339: 137-139. https://doi.org/10.1007/ BF00008921

Leksawasdi, P., 2010. Compendium of research on selected edible insects in northern Thailand. In: Durst, P.B., Johnson, D.V., Leslie, R.L. and Shono, K.E. (eds) Forest insects as food: humans bite back, proceedings of a workshop on Asia-Pacific resources and their potential for development. Food and Agriculture Organization of the United Nations. Regional Office for Asia and the Pacific, Bangkok, Thailand, pp. 183-188. Available at: http://www.fao.org/3/ i1380e/i1380e00.htm.

Lock, E.-J., Biancarosa, I. and Gasco, L., 2018. Insects as raw materials in compound feed for aquaculture. In: Halloran, A., Flore, R., Vantomme P. and Roos, N. (eds) Edible insects in sustainable food systems. Springer International Publishing, Cham, Switzerland, pp. 263-276. https://doi.org/10.1007/978-3-319-74011-9_16

Locklin, J., Huckabee, J. and Gering, E., 2012. A method for rearing large quantities of the damselfly, Ischnura ramburii (Odonata: Coenagrionidae), in the laboratory. The Florida Entomologist 95: 273-277. https://doi.org/10.2307/23268544
Macadam, C.R. and Stockan, J.A., 2017. The diversity of aquatic insects used as human food. Journal of Insects as Food and Feed 3: 203-209. https://doi.org/10.3920/JIFF2016.0046

Malmqvist, B., 1994. Preimaginal blackflies (Diptera: Simuliidae) and their predators in a central Scandinavian lake outlet stream. Annales Zoologici Fennici 31: 245-255.

Mason, W.T. and Lewis, P.A., 1970. Rearing devices for stream insect larvae. The Progressive Fish-Culturist 32: 61-62. https://doi. org/10.1577/1548-8640(1970)32[61:RDFSIL]2.0.CO;2

McPherson, J.E., 1966. Notes on the laboratory rearing of Notonecta hoffmanni (Hemiptera: Notonectidae). The Pan-Pacific entomologist 42: 54-56.

Merritt, R.W. and Wallace, J.B., 2009. Aquatic habitats. Chapter 12. In: Resh, V.H. and Cardé, R.T. (eds) Encyclopedia of insects ( $2^{\text {nd }}$ Ed.). Academic Press, San Diego, CA, USA, pp. 38-48. https://doi. org/10.1016/B978-0-12-374144-8.00012-6

Okedi, J., 1992. Chemical evaluation of Lake Victoria lakefly as nutrient source in animal feeds. Insect Science and its Application 13: 373376. https://doi.org/10.1017/S1742758400013655

Pemberton, R.W., 1995. Catching and eating dragonflies in Bali and elsewhere in Asia. American Entomologist 41: 97-99. https://doi. org/10.1093/ae/41.2.97

POGOGI, 2012. World's sushi database. Available at: https://pogogi. com/interesting-japanese-delicacies.

Polhemus, J.T. and Polhemus, D.A., 2008. Global diversity of true bugs (Heteroptera; Insecta) in freshwater. Hydrobiologia 198: 379-391. https://doi.org/10.1007/s10750-007-9033-1

Ramos-Elorduy, J., 2006. Threatened edible insects in Hidalgo, Mexico and some measures to preserve them. Journal of ethnobbiology and ethnomedicine 2: 51. https://doi.org/10.1186/1746-4269-2-51

Ramos-Elorduy, J., Pino Moreno, J.M. and Martinez Camacho, V.H., 2009. Edible aquatic Coleoptera of the world with an emphasis on Mexico. Journal of Ethnobiology and Ethnomedicine 5: 11. https:// doi.org/10.1186/1746-4269-5-11

Raybould, J.N., 1967. A method of rearing Simulium damnosum Theobald (Diptera; Simuliidae) under artificial conditions. Bulletin of the World Health Organization 37: 447-453.

Resh, V.H. and Rosenberg, D.M., 2015. Economic aspects of freshwater invertebrates. Chapter 6. In: Thorp, J.H. and Rogers, D.C. (eds) Thorp and Covich's freshwater invertebrates ( $4^{\text {th }} E d$.). Academic Press, Boston, MA, USA, pp. 93-109. https://doi.org/10.1016/ B978-0-12-385026-3.00006-1

Shantibala, T., Lokeshwari, R.K. and Debaraj, H., 2014. Nutritional and antinutritional composition of the five species of aquatic edible insects consumed in Manipur, India. Journal of Insect Science 14: 14. https://doi.org/10.1093/jis/14.1.14

Shaw, P.-C. and Mark, K.-K., 1980. Chironomid farming - a means of recycling farm manure and potentially reducing water pollution in Hong Kong. Aquaculture 21: 155-163. https://doi.org/10.1016/00448486(80)90024-1

Tao, J. and Li, Y.O., 2018. Edible insects as a means to address global malnutrition and food insecurity issues. Food Quality and Safety 2: 17-26. https://doi.org/10.1093/fqsafe/fyy001 
Van Itterbeeck, J. and Van Huis, A., 2012. Environmental manipulation for edible insect procurement: a historical perspective. Journal of Ethnobiology and Ethnomedicine 8: 1-19. https://doi. org/10.1186/1746-4269-8-3

Vancsa, E., Csata, Z. and Rakosy, L., 2014/15. Adaptation of a simple technique for rearing lotic mayflies (Insecta: Ephemeroptera) nymphs. Entomologica Romanica 19: 5-12.

Vladimirova, V.V., 1966. Mass breeding of Aedes aegypti mosquitoes. In: Technical Translation FSTC-HT-23-603-68; Department of the Army, USSR Medical Parasitology and Parasitic Diseases. Volume 35, pp. 719-723.

Waltz, R.D. and Burian, S.K., 2008. Ephemeroptera. In: Meritt, R.W., Cummins, K.W. and Berg, M.B. (eds) An introduction to the aquatic insects of North America. Kendall Hunt, Dubuque, IA, USA, pp. 181-236.

Wang, Z.-A. and Chen, P.-H., 2018. Conserving the giant water bug (Lethocerus indicus) by eco-friendly farming. Available at: https:// satoyama-initiative.org/case_studies/conserving-the-giant-waterbug-lethocerus-indicus-by-eco-friendly-farming/.

Williams, D.D., 2006. The biology of temporary waters. Oxford University Press, Oxford, UK, 337 pp.
Williams, D. and Williams, S., 2017. Aquatic insects and their potential to contribute to the diet of the globally expanding human population. Insects 8: 72. https://doi.org/10.3390/insects8030072

Williams, D.D. and Feltmate, B.W., 2017. Aquatic insects. Blackburn Press, Caldwell, NJ, USA, 372 pp.

Yhoung-aree, J., 2010. Edible insects in Thailand: nutritional values and health concerns. In: Durst, P.B., Johnson, D.V., Leslie, R.L. and Shono, K.E. (eds) Forest insects as food: humans bite back, proceedings of a workshop on Asia-Pacific resources and their potential for development. Food and Agriculture Organization of the United Nations. Regional Office for Asia and the Pacific, Bangkok, Thailand, pp. 201-216. Available at: http://www.fao.org/3/ i1380e/i1380e00.htm.

Yokoyama, A., Hamaguchi, K., Ohtsu, K., Ishihara, S., Kobara, Y., Horio, T. and Endo, S., 2009. A method for mass-rearing caddisfly, Cheumatopsyche brevilineata (Iwata) (Trichoptera: Hydropsychidae), as a new test organism for assessing the impact of insecticides on riverine insects. Applied Entomology and Zoology 44: 195-201. https://doi.org/10.1303/aez.2009.195

Yoon, T., Kim, D.G., Kim, S., Jo, S. and Bae, Y., 2010. Light-attraction flight of the giant water bug, Lethocerus deyrolli (Hemiptera: Belostomatidae), an endangered wetland insect in East Asia. Aquatic Insects 32: 195-203. https://doi.org/10.1080/01650424.2010.508045 
